Adv Chronic Kidney Dis. 2014 January ; 21(1): . doi:10.1053/j.ackd.2013.10.001.

\title{
Hereditary Renal Cancer Syndromes
}

\author{
Naomi B. Haas, M.D. [Associate Professor of Medicine] and \\ Department of Medicine, Division of Hematology/Oncology, Perelman School of Medicine at the \\ University of Pennsylvania, Tel: 215-662-7402, Fax: 215-349-8550
}

\section{Katherine L. Nathanson, M.D. [Associate Professor]}

Department of Medicine, Division of Translational Medicine and Human Genetics, Perelman

School of Medicine at the University of Pennsylvania, Tel: 215-573-9840, Fax: 215-573-7945

Naomi B. Haas: naomi.haas@uphs.upenn.edu; Katherine L. Nathanson: knathans@exchange.upenn.edu

\begin{abstract}
Inherited susceptibility to kidney cancer is a fascinating and complex topic. Our knowledge about types of genetic syndromes associated with an increased risk of disease is continually expanding. Currently, there are 10 syndromes associated with an increased risk of all types of renal cancer, which are reviewed herein. Clear cell renal cancer is associated with von Hippel Lindau disease, chromosome 3 translocations, PTEN hamartomatous syndrome and mutations in BAPl, as well as several of the genes encoding the proteins comprising the succinate dehydrogenase complex $(S D H B / C / D)$. Type 1 papillary renal cancers arise in conjunction with germline mutations in $M E T$ and type 2 as part of Hereditary Leiomyomatosis and Renal Cell Cancer ( $F H$ mutations).

Chromophone and oncocytic renal cancers are predominantly associated with Birt Hogg Dubé syndrome. Angiomyolipomas are commonly and their malignant counterpart epitheliod angiomyolipomas rarely are found in patients with Tuberous Sclerosis Complex. The targeted therapeutic options for the renal cancer associated with these diseases are just starting to expand, and are an area of active clinical research.
\end{abstract}

\section{Keywords}

von Hippel Lindau disease; Birt Hogg Dube; kidney cancer; genetic susceptibility; genetic disease

\section{Introduction}

Hereditary kidney cancer accounts for 3 to 5\% of all kidney cancer; however this number is likely an underestimate. Currently, ten inherited cancer susceptibility syndromes are associated with inherited risk of kidney cancer and 12 genes have been identified (Table 1). The number of families with identified hereditary conditions leading to kidney cancer continues to increase. The description of families with inherited syndromes associated with an increased risk kidney cancer has and will lead to the discovery of mutated gene critical to the pathogenesis of kidney cancers. Patients with these inherited syndromes develop kidney cancer at an earlier age; furthermore the lesions can be multifocal, bilateral and

\footnotetext{
(C) 2013 The National Kidney Foundation, Inc. Published by Elsevier Inc. All rights reserved.

Correspondence to: Katherine L. Nathanson, knathans @exchange. upenn. edu.

Conflict of interest: No conflict of interest for either author.

Publisher's Disclaimer: This is a PDF file of an unedited manuscript that has been accepted for publication. As a service to our customers we are providing this early version of the manuscript. The manuscript will undergo copyediting, typesetting, and review of the resulting proof before it is published in its final citable form. Please note that during the production process errors may be discovered which could affect the content, and all legal disclaimers that apply to the journal pertain.
} 
heterogeneous. Herein, we describe the most prevalent of these syndromes. Many of the gene identified through the study of familial renal cancer have also proven to be important in sporadic rneal cancers with von Hippel Lindau disease (VHL) being the exemplar of this paradigm. The recent Cancer Genome Atlas and other massively parallel sequencing studies will no doubt raise our awareness of other processes important to causality and aggressive behavior, related to the inherited genetics of kidney cancer.

\section{von Hippel Lindau (vHL) Disease}

Patients with this autosomal dominant cancer susceptibility syndrome can present with a wide spectrum of hemangioblastomas of the brain, spine and retina, pancreatic and renal cysts and neuroendocrine tumors, endolympatic sac tumors and pheochromocytomas. Some but not all patients develop clear cell renal cancer presenting as bilateral and sometimes hundreds of lesions within the kidney.

The first patients with this syndrome were described in 1860 and it recognized as a familial by Von Hippel some thirty years later; Lindau recognized that the retinal lesions were part of a larger heritable syndrome that affected the central nervous system. ${ }^{1,2}$ In 1993, the (loss of) gene responsible for these families and von Hippel-Lindau disease (vHL), VHL, was found through the study of multiple case families to be located at $3 \mathrm{p} 25-26{ }^{3-6}$

In vHL disease, there is significant variation in phenotype, which had been observed prior to gene identification. ${ }^{7}$ Subsequent to the identification of the vHL gene, a strong genotypephenotype correlation was seen with mutational type predictive of disease. ${ }^{8}$ Patients with type 1 mutations (in general, truncating mutations) have a decreased incidence of pheochromocytoma as compared to those with type 2 mutations (in general, missense mutations). ${ }^{9-12}$ Families with type 2 mutations have either a high (type $2 \mathrm{~A}$ ) or low risk of ccRCC (type 2B); type 2C families only develop pheochromocytoma. Type 2A disease is associated with the "Black Forest' founder mutation (Tyr98His) originating from southwestern Germany, which is commonly found in the 'Pennsylvania Dutch' population. ${ }^{13}$

vHL occurs in all ethnic groups at a rate of 1 in 35,000 people. ${ }^{14}$ Ninety percent of people with vHL will manifest disease findings by age $65 .{ }^{15}$ Genetic testing for mutations in $V H L$, which includes screening for point mutations as well as large deletions, detects nearly $100 \%$ of individuals with vHL disease. ${ }^{16}$ Twenty to twenty-five percent of patients are the first person in their families to develop vHL disease. There have been several case reports of mosaicism for a $V H L$ mutation identified in parents when children were diagnosed with vHL. ${ }^{17,18}$ Gondal mosaicism, which more than one children have vHL, without either parent being affected also has been observed (Nathanson, unpublished).

The $V H L$ gene is a classic tumor suppressor and loss of the wild type allele is found in hemangioblastomas, pancreatic neuroendocrine tumors, renal cysts and clear cell renal cancer from patients with vHL. ${ }^{19-22}$ The wild type allele of VHL is lost consistently in renal cysts in vHL pateints, suggesting that loss of that allele is an important initiating event in tumorigenesis. ${ }^{22} \mathrm{pVHL}$ (VHL protein) contains two functional domains, the $\alpha$ - and $\beta$ domain, which are involved in binding to elongin $\mathrm{C}$ and pVHL substrates, respectively. ${ }^{23-26}$ $V H L$ encodes an E3 ligase the major substrate of which are the hypoxia-inducible factors (HIFs), transcription factors that regulate a broad program of hypoxia-responsive genes including vascular endothelial growth factor (VEGF). ${ }^{27}$ Inactivation of $V H L$ results in upregulation of hypoxia inducible factor (HIF)- $1 a$ and $-2 a$, which drive angiogenesis and proliferation, and in addition, have profound effects on energy metabolism. ${ }^{28} \mathrm{VHL}$ is mutated not only in inherited ccRCC, but also in most sporadic ccRCCs with both copies 
lost in $86 \%$ and genetic or epigenetic changes found in $96 \% .{ }^{29}$ Studies by our group at Penn further identified two subgroups of VHL-inactivated clear cell cancers, one with a HIF-1a and $-2 a$ driven genotype, and another with a HIF-2a dominant genotype..$^{30,31}$ The HIF-2a genotype is associated with a c-myc-driven metabolic pathway and upregulation of DNA damage response, specifically double strand break repair. Discovery and characterization of the VHL pathway has been critical to the development of drug therapies for sporadic clear cell renal carcinoma.

Frameshift and nonsense mutations in $V H L$ are associated with a high penetrance of clear cell renal cancer, with risk at age 50 of $70 \% .^{9}$ Full and partial gene deletions of $V H L$ confer a lower risk, at age 50 of $40 \%$. As discussed above, type $2 \mathrm{~A}$ missense mutations also confer a high risk of renal cancer, whereas other missense mutations, types $2 \mathrm{~B}$ and $2 \mathrm{C}$, do not appear to be associated with renal cancer. ${ }^{32}$ Type $2 \mathrm{~B}$ mutations have been characterized as 'deep missense' mutations, meaning they are buried within the core of the protein when it is normally folded. ${ }^{33}$ Type $2 \mathrm{~B}$ mutations impair binding of Elongin $\mathrm{C}$ to $\mathrm{pVHL}$, while $2 \mathrm{~A}$ do not impair binding but are within the HIF-binding site ( $\beta$-domain). ${ }^{34}$ Knauth et al. showed that VHL 2A mutations had higher stability and higher ubiquitin ligase activity in respect to HIF1a, as compared to $2 \mathrm{~B}$ mutations. ${ }^{35} \mathrm{Li}$ et al. demonstrated that $2 \mathrm{~A}$ mutations retain their ability to regulate HIF1a and HIF2a. ${ }^{33}$ In contrast, 2A mutations have associated with the retention of HIF2a activity and increased growth in contrast to 2B mutations. These data implicate a biological difference accounting for the variability risk of renal cancer associated with different types of renal cancer.

\section{Treatment of vHL}

Increased awareness of this disease has led to earlier diagnosis and intervention. Familial genetic screening, routine imaging, and an aggressive surgical approach to kidney tumors in early stage disease can help prolong quality of life with low morbidity. As these patients present with multifocal disease at an early age and the tumors vary in aggressiveness, every effort should be made to preserve renal function through nephron sparing approaches (partial nephrectomy, thermal ablative therapies, or observation) in these patients with disease limited to the kidneys. However, in patients with locally advanced disease, the likelihood of recurrent disease and end-stage renal disease is much higher, and thus bilateral resection of the kidneys followed by renal transplantation is a more accepted approach. ${ }^{36} \mathrm{In}$ contemporary series, $85-90 \%$ of vHL patients now are diagnosed with renal masses less than $6 \mathrm{~cm}$, and only $11 \%$ of patients have progressed to distant metastases. ${ }^{37}$ Given the low reported rate of metastasis among patient with sporadic renal cortical neoplasms less than three $\mathrm{cm}$ in size, investigators have adopted a policy of initial observation for tumors less than $3 \mathrm{~cm}$ in size and immediate intervention for lesions greater than $3 \mathrm{~cm}$ in vHL patients. Over a follow-up of 5 years, Walther et al. reported no evidence of metastatic disease progression and no need for renal transplantation or dialysis among 52 patients with tumors less than $3 \mathrm{~cm}$ at diagnosis. In contrast, distant metastases developed in 11 of 44 patients (25\%) with lesions greater than $3 \mathrm{~cm}$ in size, including 3 of 27 patients (11\%) with lesions between 3 and $6 \mathrm{~cm} .{ }^{37} \mathrm{In}$ an update of this series, Duffey et al. confirmed the safety of this approach. ${ }^{38}$ Over a median follow-up of 41 months, all 108 patients with lesions less than 3 $\mathrm{cm}$ remained free of distant metastases, all avoided renal transplantation and dialysis, 37 (34\%) remained on observation without intervention and 104 (96\%) retained both kidneys. Of the 71 patients (66\%) that required intervention for interval growth of lesions $>3 \mathrm{~cm}$, an average of 1.7 procedures per patient was performed and $97 \%$ of these were nephronsparing (partial nephrectomy or percutaneous ablative procedures). In contrast, of the 63 patients with lesions greater than $3 \mathrm{~cm}$ who underwent treatment for renal tumors, a nephron-sparing approach was successfully employed in only $68 \%$ of instances and only 34 patients (54\%) retained both kidneys at their last follow-up. 


\section{Clinical trials in VHL mutant disease}

The studies of $V H L$ mutational status as a prognostic marker in advanced sporadic RCC have been inconsistent. Choueiri et al. examined $V H L$ status as a predictive biomarker in 123 patients treated with a variety of VEGF-inhibitors suggested that loss of function mutations in $V H L$ were associated with treatment response. ${ }^{39}$ There are ongoing clinical trials using the current VEGF-tyrosine kinase inhibitors specifically in patients with vHL (http://www.clinicaltrials.gov). As these patients often have hemangioblastomas in extrarenal sites, the goals of these therapies are to control malignant disease but also to temper symptoms from hemangioblastomas. Thus the dose of agent and the duration of therapy as well as tolerability are important issues.

Other trials specific to $V H L$ mutation in sporadic clear cell RCC are ongoing. Recently, a pilot study was conducted testing the feasibility of vaccinating advanced RCC patients with the corresponding mutant VHL peptides. ${ }^{40}$ A mutant VHL peptide vaccine was administered to six patients with $V H L$ mutant RCC. Four out of five evaluable patients $(80 \%)$ generated specific immune responses against the corresponding mutant VHL peptides. The vaccine was well tolerated. No grade III or IV toxicities occurred. The median overall survival (OS) and median progression-free survival (PFS) were 30.5 and 6.5 months, respectively.

Additionally, since the $V H L$ gene is functionally lost through hypermethylation in up to $19 \%$ of sporadic ccRCC cases, re-expressing VHL silenced by methylation in ccRCC cells, using a hypo-methylating agent, may be an approach to treatment in patients with this type of cancer. A pilot experiment was conducted in mouse xenografts using two hypo-methylating agents to re-express VHL in cell culture and in mice bearing human ccRCC and evaluate the effects of re-expressed VHL in these models. ${ }^{41}$ Real-time reverse transcription-PCR was used to evaluate the ability of zebularine and 5-aza-2'-deoxycytidine (5-aza-dCyd) to reexpress VHL in four ccRCC cell lines with documented VHL gene silencing through hypermethylation as well as in vHL methylated ccRCC xenografted tumors. 5-Aza-dCyd was able to re-express VHL in our cell lines both in culture and in xenografted murine tumors. Well described phenotypic changes of VHL expression including decreased invasiveness into Matrigel, and decreased vascular endothelial growth factor and glucose transporter-1 expression were observed in the treated lines. VHL methylated ccRCC xenografted tumors were significantly reduced in size in mice treated with 5-aza-dCyd. Mice bearing nonmethylated but $V H L$-mutated tumors showed no tumor shrinkage with 5-azadCyd treatment.

\section{Hereditary papillary renal cancer}

\section{Hereditary papillary renal cell carcinoma (type 1 papillary)}

Hereditary papillary renal cell carcinoma (HPRCC) is an autosomal dominant syndrome characterized by multifocal, bilateral type I papillary renal cell carcinomas. ${ }^{42,43}$ Mutations of the MET gene on 7q31 have been causally associated with HPRCC, ${ }^{44-48}$ but $M E T$ is mutated in less than $10 \%$ of sporadic type papillary renal cancers. Families with inherited mutations in MET leading to multi-focal papillary renal cancer (type 1) are quite rare, much more so than vHL, and most of the other described inherited renal cancer syndromes, including HLRCC and BHD.

\section{Hereditary leiomyomatosis and renal cell cancer (type 2 papillary)}

Hereditary leiomyomatosis and renal cell cancer (HLRCC) is an autosomal cancer susceptibility syndrome characterized by the development of cutaneous and uterine leiomyomas and renal cancer. ${ }^{49,50}$ Papillary type 2 renal cancer is the pathological type most commonly associated with HLRCC, and tends to have an early age of onset, be high grade 
and have an aggressive course. ${ }^{51}$ The mean age of renal cancer diagnosis is 40 , but metastatic renal cancer can present in the teens. Other types of renal cancers also can occur, including collecting duct and clear cell cancers. ${ }^{50,52,53}$ Independent of underlying architecture, cells in the renal cancers associated with HLRCC have a characteristic pathological appearance with large nuclei with inclusion-like orangiophilic or eosinophilic nucleoi surrounded by a clear halo, which can be recognized by knowledgeable pathologists. ${ }^{51}$

The gene fumarate hydratase $(F H)$, which encodes the enzyme which converts fumarate to malate in the Kreb's cycle, is mutated in HLRCC. ${ }^{53,54}$ All types of point mutations have been reported, with missense mutations by far the most predominant $(57 \%$; 191/337) in the FH mutation database (http://chromium.liacs.nl/lovd_sdh/home.php?select_db=FH). ${ }^{55}$ The lower fumarate hydratase enzymatic activity found in affected patients has been proposed as a method for screening of family members, however genetic testing remains a more efficient method to detect affected individuals. ${ }^{56}$

Intrafamilial heterogeneity has been observed in multiple cases, despite similar decreases in FH activity ${ }^{57}$ The penetrance for the complete phenotypic manifestations of HLRCC has yet to be fully defined, although similarly to many cancer susceptibility syndromes, as more families are tested, individuals with mutations but no manifestations of disease have been identified. No modifiers of penetrance have yet been identified. ${ }^{58}$

The mutated FH gene behaves as a tumor suppressor gene, as loss of the wild type allele is observed in renal cancer from individuals with $F H$ mutations. Patients with biallelic mutations (homozygous or compound heterozygotes) develop Fumarate Hydratase Deficiency (FHD) characterized by fumaric aciduria, progressive encephalopathy, hypotonia, failure to thrive and seizures. ${ }^{59-62}$ These patients usually do not survive beyond the first few months of life, although some more mildly affected individuals have been described. ${ }^{63,64}$ Relatives with only one mutation, can go on to develop papillary type 2 renal cancer. Mutations have not been observed in sporadic RCC, but in part the lack of observation may arise due to the limited number of papillary type 2 tumors included in the screening series. ${ }^{57}$

In renal cancers with fumarate hydratase mutations, HIF accumulation increases when high levels of fumarate inhibit the HIF proline hydoxylases and increased transcription of downstream targets. ${ }^{65}$ The perturbation of metabolic intermediates has the potential to alter function of several other 2-oxoglutarate-dependent enzymes including a family of histoneregulating demethylases that have in common a jumonji-C domain, several of which have been linked to kidney cancer. This metabolic-epigenetic link is of high interest, given the newly recognized epigenetic findings in renal cell carcinoma. Two studies have demonstrated that FH loss results on activation of Nrf2-dependent activation of antioxidant pathways. ${ }^{66,67} \mathrm{NRF} 2$, a transcription factor, is a key regulator of the antioxidant response, with multiple target genes that contain NRF2 response elements. ${ }^{68}$ Cellular levels of NRF2 are regulated by KEAP1 (Kelch-like ECH-associated protein 1), which is the substrate recognition subunit of a Cul3-based E3 ubiquitin ligase. Through tandem mass spectrometry, Ooi et al. and Adam et al. showed that fumarate modifies critical cysteine residues (Cys155 and Cys288) within KEAP1, so that it is unable to bind to NRF2 and target it for degradation. ${ }^{66,67}$ Upregulation of NRF2 may be an alternative pathway, other than through 'pseudohypoxia', which may lead to FH-deficient associated tumorigenesis, although the exact mechanism remains to be elucidated. Additionally, diminished AMPK is found in FH deficient renal cancer, which facilitates increased fatty acid and protein biosynthesis, as decreased iron and increased HIF-1a levels. ${ }^{69}$ 
Immunohistochemistry for $\mathrm{FH}$ is not a reliable marker to detect renal papillary type II tumors associated with HLRCC which contain missense mutations in $F H$, as these leave stable but inactive protein. Fumarate reacts spontaneously with cysteine sulphydryl groups to chemically modify proteins in process termed succination. Therefore, immunohistochemistry for S-(2-succinyl) cysteine (2SC) has been proposed as a marker of FH loss, and thus mutations in $\mathrm{FH}^{70}$ and has been validated in over 1000 specimens. ${ }^{70,71}$ Use of immunochemistry to identify patients who need evaluation for HLRCC and subsequent genetic testing for mutations in $\mathrm{FH}$ may become part of clinical practice. Array based comparative genomic hybridization $(\mathrm{aCGH})$ has been done to characterize $\mathrm{FH}$ deficient renal cancers. Loss of chromosome 1q was found as expected consistent with the tumor suppressor role of $F H$, as was gains of chromosomes 2, 7, 17 and losses of 13q12q21.1, 14, 18 and $\mathrm{X}$, suggesting a distinct genetic profile for these renal tumors. ${ }^{72}$ However, specific genetic associations have not yet been identified.

Uterine leiomyomas (fibroids) are benign tumors that arise from the smooth muscle cells of the uterus. They are the most frequent non-renal manifestation of HLRCC and develop in $75-98 \%$ of women. ${ }^{53,73,74}$ The leiomyomas tend to be early onset and severe, diagnosed on average 10 years earlier than in sporadic disease, with $68 \%$ diagnosed before the age of 30 in one series. ${ }^{53,75}$ The histopathology of the uterine leiomyomas associated with HLRCC appear to be quite similar to the renal tumors, in particular the nuclear features with prominent eosinophilic nucleoli surrounded by a clear halo. ${ }^{76}$ Cutaneous leiomyomas (piloleiomyomas) are painful pink-purplish nodules that affect individuals in a disseminated or segmental distribution. Cutaneous leiomyomas are benign tumors that arise from the piloerector apparatus. ${ }^{49}$ Cutaneous leiomyomas occur in $80-100 \%$ of individuals with a mean age of presentation of 25 years (range 10-47 years), but can develop later into the 40 s. ${ }^{77}$

\section{Other tumor manifestations}

Wilm's tumor has been reported in two pediatric patients with FH mutations, suggesting a possible associated predisposition. ${ }^{54,78}$ Leydig cell tumors also have been reported in patient with HLRCC. Screening of sporadic leydig cell tumors also identified a second male with a germline mutation, suggesting that patients with leydig cell tumors should be asked about pertinent family history. ${ }^{79}$ Gastrointestinal stromal tumors (GIST), adrenocortical disease and ovarian cystadenomas also have been described in patients with HLRCC. ${ }^{80,81}$

\section{Trials for papillary RCC}

Clinical trials of MET inhibitors for type 1and 2 papillary renal cancers, including foretinib, cabozantinib and arq 197 have been completed or are underway (www.clinicaltrials.govv). ${ }^{82}$ A phase II trial of two dosing schedules of foretinib, an oral multikinase inhibitor targeting MET, VEGF, RON, AXL, and TIE- 2 receptors, was conducted in 74 patients with metastatic papillary RCC based on MET pathway activation (germline or somatic MET mutation, MET [7q31] amplification, or gain of chromosome $7 .{ }^{83}$ The primary end point was overall response rate (ORR). The presence of a germline MET mutation was highly predictive of a response (five of $10 \mathrm{vs.} \mathrm{five} \mathrm{of} 57$ patients with and without germline MET mutations, respectively). The most frequent adverse events of any grade associated with foretinib were fatigue, hypertension, gastrointestinal toxicities, and nonfatal pulmonary emboli. In another trial of $150 \mathrm{mg}$ once daily erlotinib, an oral epidermal growth factor receptor (EGFR) tyrosine kinase inhibitor, was evaluated in histologically confirmed, advanced, or metastatic pRCC where the overall RR was $11 \%$ (five of 45 patients; $95 \% \mathrm{CI}$, $3 \%$ to $24 \%$ ), and the disease control rate was $64 \%$ (ie five partial response and 24 stable disease) ${ }^{84}$ The median overall survival time was 27 months (95\% CI, 13 to 36 months). Probability of freedom from treatment failure at 6 months was $29 \%$ (95\% CI, 17\% to $42 \%$ ). 
There was one grade 5 adverse event (AE) of pneumonitis, one grade 4 thrombosis, and nine other grade 3 AEs.

\section{Birt-Hogg-Dubé disease}

Patients with Birt-Hogg-Dubé disease (BHD) have an autosomal dominant syndrome characterized by the development of fibrofolliculomas (dysplastic hair follicules), lung cysts and spontaneous pneumothorax, and renal cancer. ${ }^{85,86}$ This syndrome occurs in approximately 1 of 200,000 people and is underdiagnosed due to its variable, and often mild, presentation. The gene for BHD maps to 17p12q11.2, was identified through linkage in affected families, and thus named folliculin $(F L C N) .{ }^{87}$ Both point mutations and large genomic rearrangements have been found in $F L C N$, and are causative of BHD. ${ }^{88}$ The FLCN protein has no homology to previously identified proteins, and its function has been controversial. Most recently, it has been suggested that it is a ciliopathy, is involved in cell polarity, regulates cell-cell adhesion and negative regulates rRNA synthesis. ${ }^{89-91} \mathrm{~A}$ wide spectrum of renal cancers (papillary RCC, ccRCC, mixed and oncocytomas) has been observed in patients with BHD, even within the same kidney. ${ }^{92}$ The renal parenchyma surrounding the renal tumor can often contain multifocal oncocytosis. The most common type of tumor is an unusual hybrid oncocytic tumor (mixed oncocytoma and chromophobe). Because a hybrid oncocytic tumor is characteristic of BHD, any patient presenting with one should be evaluated for BHD. FCLN functions as a tumor suppressor gene in BHD; mutations in $F L C N$ have been identified in sporadic chromophobe renal cancers, although not commonly. ${ }^{93,94}$

Criteria for the diagnosis of BHD have been proposed and include major criteria of 1) at least five fibrofolliculomas, at least one histologically confirmed, of adult onset or 2) pathogenic FLCN mutation and minor criteria of 1) multiple lung cysts: bilateral basally located lung cysts with no other apparent cause, with or without spontaneous pneumothorax; 2 ) renal cancer: early onset ( $<50$ years) or multifocal or bilateral renal cancer, or renal cancer of mixed chromophobe and oncocytic histology; and 3) a first degree relative with BHD. ${ }^{95}$ Patients should have one major or two minor criteria for diagnosis. BHD is vastly under diagnosed.

\section{Treatment of BHD-associated kidney cancer}

Chromophobe tumors when diagnosed early are often curable with surgery. Metastatic disease, especially if the histology is chromophobe, is challenging to treat due to the rarity of the presentation and the lack of defined therapeutic targets. Sporadic chromophobe tumors can contain mutations in $K I T,{ }^{96}$ but it is unknown if treatment with imatinib or sunitinib which have kit as a target, are active.

\section{Other inherited syndromes with an increased risk of renal cancer}

\section{BAP1 mutations and familial renal cancer}

Somatic mutations in $B A P 1$ (BRCA associated protein 1) were identified through whole exome sequencing studies. ${ }^{97}$ BAP1 mutations have been associated with a higher tumor grade and decreased overall survival, as compared to those with PBRM1 mutations, which are negatively correlated. ${ }^{98}$ In the massively parallel sequencing of clear cell renal cancer, germline mutations also were identified. Two recent studies have suggested that BAPl mutations predispose to familial clear cell renal cancer, along with uveal and cutaneous melanoma and mesothelioma. ${ }^{99,100}$ 


\section{Chromosome 3 translocations}

Multiple families with inherited susceptibility due to balanced translocations involving chromosome 3 have been described. ${ }^{101-106}$ The mechanism behind the increased risk of multi-focal clear cell renal cancer is thought to be loss of the rearranged chromosome during mitosis, which requires a quadrivalent (four chromosomes coming together), leading to greater errors during chromosomal segregation. As multiple genes involved in the pathogenesis of clear cell renal cancer are located on chromosome 3p, including $V H L$, $P B R M 1, B A P 1$, and SETD2, ${ }^{107}$ it is not surprising that a mechanism of increased loss of one allele leads to an increased risk of clear cell renal cancer.

\section{PTEN hamartoma tumor syndrome (Cowden disease)}

PTEN is associated with an increased risk of benign and malignant tumors of the thyroid, breast and endometrium caused by mutations in PTEN. ${ }^{108}$ Dermatological manifestations of Cowden syndrome are very common, seen in essentially all patients by their 30 s, and include trichilemmomas, papillomatous papules, and acral and plantar keratoses. ${ }^{109}$ Clear cell renal cancer has been reported as a observed in patients with Cowden syndrome, with recent estimates suggesting a standardized incidence ratio of 30.6 (95\% CI 17.8, 49.4). ${ }^{110-112}$ One study has shown the loss of the wild type PTEN allele in a renal cancer from a Cowden syndrome patient. ${ }^{111}$ A study of sporadic renal cancers and cell lines have shown that mutations in PTEN are present, particularly in late stage and clear cell renal cancers. ${ }^{113}$

\section{SDH- associated paraganglioma/pheochromocytoma}

Mutations in three of the four proteins $(S D H B / C / D)$ comprising the succinate dehydrogenase complex, which participates in both the Krebs cycle, converting fumarate to succinate and as mitochondrial respiratory chain complex II, have been associated with an increased risk of renal cancer. ${ }^{114}$ Patients with mutations in the SDH genes have an increased risk of developing tumors of the autonomic nervous system - pheochromocytomas and paragangliomas, both head and neck, and in the thorax and abdomen. ${ }^{115}$ Germline $S D H B$ mutations are associated with increased risk of metastatic disease as compared to mutations in the other genes of the SDH complex, all of which are associated with an increased risk of pheochromocytomas and paragangliomas. ${ }^{116}$ Patients can develop a variety of RCCs including clear cell, chromophobe, and oncocytomas. ${ }^{117-119}$ These renal tumors recently have been reported to be particularly aggressive. ${ }^{120}$

\section{Tuberous Sclerosis Complex}

Tuberous Sclerosis Complex (TSC) is a autosomal dominant genetic disorder characterized by the formation of hamartomas in multiple organs, including brain, kidney, skin and lung. The formation of hamartomas leads to neurologic disorders, including epilepsy, mental retardation, and autism as well as dermatologic manifestations such as facial angiofibromas, renal angiomyolipomas, and pulmonary lymphangiomyomatosis. ${ }^{121}$ Inactivating mutations in TSC1 (chromosome 9q34) encoding hamartin, or TSC2 (chromosome 16p13.3) encoding tuberin are responsible for the phenotype. ${ }^{122-124}$ The mutations occur as spontaneous germline mutations in $70 \%$ of cases; patients with TSC 2 mutations are more severely affected with greater renal involvement among other features. ${ }^{125}$ The 50 to $80 \%$ of patients with TSC who develop renal lesions can have angiomyolipomas (AMLs), cysts, oncocytomas, and renal cell carcinomas. Of affected TSC patients, 75-80\% develop AMLs and less than 5\% develop renal cancer (with precise estimates varying across studies) ${ }^{126}$. Patients can develop epitheliod angiomyolipomas, and the other more common types of renal cancer have been reported. 
Hamartin and tuberin are proteins that heterodimerize and inhibit downstream pathways of mammalian target of rapamycin (mTOR). ${ }^{121}$ Thus, inactivation of one of the genes translating these proteins leads to upregulation of the HIF pathway. mTor inhibitors including rapamycin, analogs such as everolimus, temsirolimus and dual TOR inhibitors have been used to treat patients with TSC and lymphangiomyomatosis. Recently, everolimus was FDA approved to treat angiomyolipomas (and subependymal astrocytomas) based on a double-blinded placebo controlled trial showing a response rate of $42 \%$ (95\% CI 31, 55\%) as compared to $0 \%$ in patients treated with placebo. ${ }^{127}$ This study forms the basis of the recommendation that TSC patients with multiple angiomyolipomas be treated with everolimus.

\section{Conclusion}

The identification of genes associated with inherited susceptibility to renal cancer has led to a greatly increased understanding of renal tumor pathogenesis. As mutations in each gene tend to be associated with specific pathological sub-types of renal cancer, examining the two in conjunction has allowed a more precise definition of each, thus both refining our understanding of renal tumors and associated cancer susceptibility syndromes. Patients with inhered cancer susceptibility syndromes including renal cancer are being increasingly recognized by physicians and referred for specialist evaluation, leading to improved clinical outcomes with medical management guidelines targeted for those diseases. Additionally, these advances in knowledge have further delineated aberrantly activated pathways so that cancer therapeutics can be appropriately targeted in each sub-type of renal cancer.

\section{References}

1. Von Hippel E. Uber eine sehr seltene Erkanung der netzhaut. Graefes Arch Clin Exp Opthalmol. 1904; 59:83-106.

2. Lindau A. Studien ber kleinbirncysten bau: pathogenese und beziehungen zur angiomatosis retinae. Acta Radiol Microbiol Scandinavica. 1926; 1( Suppl):1-128.

3. Richards FM, Crossey PA, Phipps ME, et al. Detailed mapping of germline deletions of the von Hippel-Lindau disease tumour suppressor gene. Hum Molec Genet. 1994; 3(4):595-598. [PubMed: 8069305]

4. Richards FM, Maher ER, Latif F, et al. Detailed genetic mapping of the von Hippel-Lindau disease tumour suppressor gene. J Med Genet. Feb; 1993 30(2):104-107. [PubMed: 8445612]

5. Richards FM, Phipps ME, Latif F, et al. Mapping the Von Hippel-Lindau disease tumour suppressor gene: identification of germline deletions by pulsed field gel electrophoresis. Hum Molec Genet. 1993; 2(7):879-882. [PubMed: 8364570]

6. Latif F, Tory K, Gnarra J, et al. Identification of the von Hippel-Lindau disease tumor suppressor gene. Science (New York, NY). May 28; 1993 260(5112):1317-1320.

7. Maher ER, Bentley E, Yates JR, et al. Mapping of the von Hippel-Lindau disease locus to a small region of chromosome 3p by genetic linkage analysis. Genomics. Aug; 1991 10(4):957-960. [PubMed: 1680799]

8. Maher ER, Webster AR, Richards FM, et al. Phenotypic expression in von Hippel-Lindau disease: correlations with germline VHL gene mutations. J Med Genet. 1996; 33(4):328-332. [PubMed: 8730290]

9. Ong KR, Woodward ER, Killick P, Lim C, Macdonald F, Maher ER. Genotype-phenotype correlations in von Hippel-Lindau disease. Hum Mutat. Feb; 2007 28(2):143-149. [PubMed: 17024664]

10. Zbar B, Kishida T, Chen F, et al. Germline mutations in the Von Hippel-Lindau disease (VHL) gene in families from North America, Europe, and Japan. Hum Mutat. 1996; 8(4):348-357. [PubMed: 8956040]

11. Hes F, Zewald R, Peeters T, et al. Genotype-phenotype correlations in families with deletions in the von Hippel-Lindau (VHL) gene. Hum Genet. 2000; 106(4):425-431. [PubMed: 10830910] 
12. Chen F, Kishida T, Yao M, et al. Germline mutations in the von Hippel-Lindau disease tumor suppressor gene: correlations with phenotype. Hum Mutat. 1995; 5(1):66-75. [PubMed: 7728151]

13. Brauch H, Kishida T, Glavac D, et al. Von Hippel-Lindau (VHL) disease with pheochromocytoma in the Black Forest region of Germany: evidence for a founder effect. Hum Genet. 1995; 95(5): 551-556. [PubMed: 7759077]

14. Maher ER, Iselius L, Yates JR, et al. Von Hippel-Lindau disease: a genetic study. J Med Genet. Jul; 1991 28(7):443-447. [PubMed: 1895313]

15. Maher ER, Yates JR, Harries R, et al. Clinical features and natural history of von Hippel-Lindau disease. Q J Med. Nov; 1990 77(283):1151-1163. [PubMed: 2274658]

16. Crossey PA, Foster K, Richards FM, et al. Molecular genetic investigations of the mechanism of tumourigenesis in von Hippel-Lindau disease: analysis of allele loss in VHL tumours. Hum Genet. 1994; 93(1):53-58. [PubMed: 8270255]

17. Murgia A, Martella M, Vinanzi C, Polli R, Perilongo G, Opocher G. Somatic mosaicism in von Hippel-Lindau Disease. Hum Mutat. Jan.2000 15(1):114. [PubMed: 10612832]

18. Sgambati MT, Stolle C, Choyke PL, et al. Mosaicism in von Hippel-Lindau disease: lessons from kindreds with germline mutations identified in offspring with mosaic parents. Am J Hum Genet. 2000; 66(1):84-91. [PubMed: 10631138]

19. Vortmeyer AO, Lubensky IA, Fogt F, Linehan WM, Khettry U, Zhuang Z. Allelic deletion and mutation of the von Hippel-Lindau (VHL) tumor suppressor gene in pancreatic microcystic adenomas. Am J Pathol. 1997; 151(4):951-956. [PubMed: 9327728]

20. Tse JY, Wong JH, Lo KW, Poon WS, Huang DP, Ng HK. Molecular genetic analysis of the von Hippel-Lindau disease tumor suppressor gene in familial and sporadic cerebellar hemangioblastomas. Am J Clin Pathol. Apr; 1997 107(4):459-466. [PubMed: 9124215]

21. Lubensky IA, Gnarra JR, Bertheau P, Walther MM, Linehan WM, Zhuang Z. Allelic deletions of the VHL gene detected in multiple microscopic clear cell renal lesions in von Hippel-Lindau disease patients. Am J Pathol. 1996; 149(6):2089-2094. [PubMed: 8952541]

22. Mandriota SJ, Turner KJ, Davies DR, et al. HIF activation identifies early lesions in VHL kidneys: evidence for site-specific tumor suppressor function in the nephron. Cancer Cell. Jun; 2002 1(5): 459-468. [PubMed: 12124175]

23. Kibel A, Iliopoulos O, DeCaprio JA, Kaelin WG Jr. Binding of the von Hippel-Lindau tumor suppressor protein to Elongin B and C. Science (New York, NY). Sep 8; 1995 269(5229):14441446.

24. Kishida T, Stackhouse TM, Chen F, Lerman MI, Zbar B. Cellular proteins that bind the von Hippel-Lindau disease gene product: mapping of binding domains and the effect of missense mutations. Cancer Res. Oct 15; 1995 55(20):4544-4548. [PubMed: 7553625]

25. Stebbins CE, Kaelin WG Jr, Pavletich NP. Structure of the VHL-ElonginC-ElonginB complex: implications for VHL tumor suppressor function. Science (New York, NY). 1999; 284(5413):455461.

26. Ohh M, Takagi Y, Aso T, et al. Synthetic peptides define critical contacts between elongin C, elongin B, and the von Hippel-Lindau protein. J Clin Invest. Dec; 1999 104(11):1583-1591. [PubMed: 10587522]

27. Cockman ME, Masson N, Mole DR, et al. Hypoxia inducible factor-alpha binding and ubiquitylation by the von Hippel-Lindau tumor suppressor protein. J Biol Chem. Aug 18; 2000 275(33):25733-25741. [PubMed: 10823831]

28. Kim W, Kaelin WG Jr. The von Hippel-Lindau tumor suppressor protein: new insights into oxygen sensing and cancer. Curr Opin Genet Dev. Feb; 2003 13(1):55-60. [PubMed: 12573436]

29. Banks RE, Tirukonda P, Taylor C, et al. Genetic and epigenetic analysis of von Hippel-Lindau (VHL) gene alterations and relationship with clinical variables in sporadic renal cancer. Cancer Res. Feb 15; 2006 66(4):2000-2011. [PubMed: 16488999]

30. Dondeti VR, Wubbenhorst B, Lal P, et al. Integrative genomic analyses of sporadic clear cell renal cell carcinoma define disease subtypes and potential new therapeutic targets. Cancer Res. Jan 1; 2012 72(1):112-121. [PubMed: 22094876] 
31. Gordan JD, Lal P, Dondeti VR, et al. HIF-alpha effects on c-Myc distinguish two subtypes of sporadic VHL-deficient clear cell renal carcinoma. Cancer Cell. Dec 9; 2008 14(6):435-446. [PubMed: 19061835]

32. Richards FM, Webster AR, McMahon R, Woodward ER, Rose S, Maher ER. Molecular genetic analysis of von Hippel-Lindau disease. J Intern Med. 1998; 243(6):527-533. [PubMed: 9681854]

33. Li L, Zhang L, Zhang X, et al. Hypoxia-inducible factor linked to differential kidney cancer risk seen with type 2A and type 2B VHL mutations. Mol Cell Biol. Aug; 2007 27(15):5381-5392. [PubMed: 17526729]

34. Clifford SC, Cockman ME, Smallwood AC, et al. Contrasting effects on HIF-1alpha regulation by disease-causing pVHL mutations correlate with patterns of tumourigenesis in von Hippel-Lindau disease. Hum Molec Genet. 2001; 10(10):1029-1038. [PubMed: 11331613]

35. Knauth K, Bex C, Jemth P, Buchberger A. Renal cell carcinoma risk in type 2 von Hippel-Lindau disease correlates with defects in pVHL stability and HIF-1alpha interactions. Oncogene. Jan 19; 2006 25(3):370-377. [PubMed: 16261165]

36. Goldfarb DA, Neumann HP, Penn I, Novick AC. Results of renal transplantation in patients with renal cell carcinoma and von Hippel-Lindau disease. Transplant. Dec 27; 1997 64(12):1726-1729.

37. Walther MM, Choyke PL, Glenn G, et al. Renal cancer in families with hereditary renal cancer: prospective analysis of a tumor size threshold for renal parenchymal sparing surgery. J Urol. May; 1999 161(5):1475-1479. [PubMed: 10210376]

38. Duffey BG, Choyke PL, Glenn G, et al. The relationship between renal tumor size and metastases in patients with von Hippel-Lindau disease. J Urol. Jul; 2004 172(1):63-65. [PubMed: 15201738]

39. Choueiri TK, Plantade A, Elson P, et al. Efficacy of sunitinib and sorafenib in metastatic papillary and chromophobe renal cell carcinoma. J Clin Oncol. Jan 1; 2008 26(1):127-131. [PubMed: 18165647]

40. Rahma OE, Ashtar E, Ibrahim R, et al. A pilot clinical trial testing mutant von Hippel-Lindau peptide as a novel immune therapy in metastatic renal cell carcinoma. J Transl Med. 2010; 8:8. [PubMed: 20109232]

41. Alleman WG, Tabios RL, Chandramouli GV, et al. The in vitro and in vivo effects of re-expressing methylated von Hippel-Lindau tumor suppressor gene in clear cell renal carcinoma with 5-aza-2'deoxycytidine. Clin Cancer Res. Oct 15; 2004 10(20):7011-7021. [PubMed: 15501981]

42. Zbar B, Glenn G, Lubensky I, et al. Hereditary papillary renal cell carcinoma: clinical studies in 10 families. J Urol. Mar; 1995 153(3 Pt 2):907-912. [PubMed: 7853572]

43. Zbar B, Tory K, Merino M, et al. Hereditary papillary renal cell carcinoma. J Urol. Mar; 1994 151(3):561-566. [PubMed: 8308957]

44. Schmidt L, Duh FM, Chen F, et al. Germline and somatic mutations in the tyrosine kinase domain of the MET proto-oncogene in papillary renal carcinomas. Nat Genet. May; 1997 16(1):68-73. [PubMed: 9140397]

45. Schmidt L, Junker K, Nakaigawa N, et al. Novel mutations of the MET proto-oncogene in papillary renal carcinomas. Oncogene. Apr 8; 1999 18(14):2343-2350. [PubMed: 10327054]

46. Lubensky IA, Schmidt L, Zhuang Z, et al. Hereditary and sporadic papillary renal carcinomas with c-met mutations share a distinct morphological phenotype. Am J Pathol. Aug; 1999 155(2):517526. [PubMed: 10433944]

47. Lindor NM, Dechet CB, Greene MH, et al. Papillary renal cell carcinoma: analysis of germline mutations in the MET proto-oncogene in a clinic-based population. Genet Test. Summer;2001 5(2):101-106. [PubMed: 11551094]

48. Dharmawardana PG, Giubellino A, Bottaro DP. Hereditary papillary renal carcinoma type I. Curr Mol Med. Dec; 2004 4(8):855-868. [PubMed: 15579033]

49. Toro JR, Nickerson ML, Wei MH, et al. Mutations in the fumarate hydratase gene cause hereditary leiomyomatosis and renal cell cancer in families in North America. Am J Hum Genet. Jul; 2003 73(1):95-106. [PubMed: 12772087]

50. Alam NA, Rowan AJ, Wortham NC, et al. Genetic and functional analyses of FH mutations in multiple cutaneous and uterine leiomyomatosis, hereditary leiomyomatosis and renal cancer, and fumarate hydratase deficiency. Hum Molec Genet. Jun 1; 2003 12(11):1241-1252. [PubMed: 12761039] 
51. Merino MJ, Torres-Cabala C, Pinto P, Linehan WM. The morphologic spectrum of kidney tumors in hereditary leiomyomatosis and renal cell carcinoma (HLRCC) syndrome. Am J Surg Pathol. Oct; 2007 31(10):1578-1585. [PubMed: 17895761]

52. Grubb RL 3rd, Franks ME, Toro J, et al. Hereditary leiomyomatosis and renal cell cancer: a syndrome associated with an aggressive form of inherited renal cancer. J Urol. Jun; 2007 177(6): 2074-2079. discussion 2079-2080. [PubMed: 17509289]

53. Wei MH, Toure O, Glenn GM, et al. Novel mutations in FH and expansion of the spectrum of phenotypes expressed in families with hereditary leiomyomatosis and renal cell cancer. $\mathrm{J}$ Med Genet. Jan; 2006 43(1):18-27. [PubMed: 15937070]

54. Smit DL, Mensenkamp AR, Badeloe S, et al. Hereditary leiomyomatosis and renal cell cancer in families referred for fumarate hydratase germline mutation analysis. Clin Genet. Jan; 2011 79(1): 49-59. [PubMed: 20618355]

55. Bayley JP, Launonen V, Tomlinson IP. The FH mutation database: an online database of fumarate hydratase mutations involved in the MCUL (HLRCC) tumor syndrome and congenital fumarase deficiency. BMC Med Genet. 2008; 9:20. [PubMed: 18366737]

56. Pithukpakorn M, Wei MH, Toure O, et al. Fumarate hydratase enzyme activity in lymphoblastoid cells and fibroblasts of individuals in families with hereditary leiomyomatosis and renal cell cancer. J Med Genet. Sep; 2006 43(9):755-762. [PubMed: 16597677]

57. Gardie B, Remenieras A, Kattygnarath D, et al. Novel FH mutations in families with hereditary leiomyomatosis and renal cell cancer (HLRCC) and patients with isolated type 2 papillary renal cell carcinoma. J Med Genet. Apr; 2011 48(4):226-234. [PubMed: 21398687]

58. Vahteristo P, Koski TA, Naatsaari L, et al. No evidence for a genetic modifier for renal cell cancer risk in HLRCC syndrome. Fam Cancer. Jun; 2010 9(2):245-251. [PubMed: 20091131]

59. Gellera C, Uziel G, Rimoldi M, et al. Fumarase deficiency is an autosomal recessive encephalopathy affecting both the mitochondrial and the cytosolic enzymes. Neurology. Mar; 1990 40(3 Pt 1):495-499. [PubMed: 2314594]

60. Bourgeron T, Chretien D, Poggi-Bach J, et al. Mutation of the fumarase gene in two siblings with progressive encephalopathy and fumarase deficiency. J Clin Invest. Jun; 1994 93(6):2514-2518. [PubMed: 8200987]

61. Coughlin EM, Christensen E, Kunz PL, et al. Molecular analysis and prenatal diagnosis of human fumarase deficiency. Mol Genet Metab. Apr; 1998 63(4):254-262. [PubMed: 9635293]

62. Bonioli E, Di Stefano A, Peri V, et al. Fumarate hydratase deficiency. J Inherit Metab Dis. Jun; 1998 21(4):435-436. [PubMed: 9700607]

63. Maradin M, Fumic K, Hansikova H, et al. Fumaric aciduria: mild phenotype in a 8-year-old girl with novel mutations. J Inherit Metab Dis. Oct.2006 29(5):683. [PubMed: 16972175]

64. Ottolenghi C, Hubert L, Allanore Y, et al. Clinical and biochemical heterogeneity associated with fumarase deficiency. Hum Mutat. May 10.2011

65. Linehan WM, Rouault TA. Molecular pathways: fumarate hydratase-deficient kidney cancer-targeting the warburg effect in cancer. Clin Cancer Res. Jul 1; 2013 19(13):3345-3352. [PubMed: 23633457]

66. Adam J, Hatipoglu E, O'Flaherty L, et al. Renal cyst formation in Fh1-deficient mice is independent of the Hif/Phd pathway: roles for fumarate in KEAP1 succination and Nrf2 signaling. Cancer Cell. Oct 18; 2011 20(4):524-537. [PubMed: 22014577]

67. Ooi A, Wong JC, Petillo D, et al. An antioxidant response phenotype shared between hereditary and sporadic type 2 papillary renal cell carcinoma. Cancer Cell. Oct 18; 2011 20(4):511-523. [PubMed: 22014576]

68. Giudice A, Arra C, Turco MC. Review of molecular mechanisms involved in the activation of the Nrf2-ARE signaling pathway by chemopreventive agents. Methods Mol Biol. 2010; 647:37-74. [PubMed: 20694660]

69. Tong WH, Sourbier C, Kovtunovych G, et al. The glycolytic shift in fumarate-hydratase-deficient kidney cancer lowers AMPK levels, increases anabolic propensities and lowers cellular iron levels. Cancer Cell. Sep 13; 2011 20(3):315-327. [PubMed: 21907923] 
70. Bardella C, El-Bahrawy M, Frizzell N, et al. Aberrant succination of proteins in fumarate hydratase-deficient mice and HLRCC patients is a robust biomarker of mutation status. J Pathol. Sep; 2011 225(1):4-11. [PubMed: 21630274]

71. Maxwell PH. Seeing the smoking gun: a sensitive and specific method to visualize loss of the tumour suppressor, fumarate hydratase, in human tissues. J Pathol. Sep; 2011 225(1):1-3. [PubMed: 21792933]

72. Koski TA, Lehtonen HJ, Jee KJ, et al. Array comparative genomic hybridization identifies a distinct DNA copy number profile in renal cell cancer associated with hereditary leiomyomatosis and renal cell cancer. Genes Chromosomes Cancer. Jul; 2009 48(7):544-551. [PubMed: 19373782]

73. Launonen V, Vierimaa O, Kiuru M, et al. Inherited susceptibility to uterine leiomyomas and renal cell cancer. Proc Natl Acad Sci U S A. Mar 13; 2001 98(6):3387-3392. [PubMed: 11248088]

74. Tomlinson IP, Alam NA, Rowan AJ, et al. Germline mutations in FH predispose to dominantly inherited uterine fibroids, skin leiomyomata and papillary renal cell cancer. Nat Genet. Apr; 2002 30(4):406-410. [PubMed: 11865300]

75. Stewart L, Glenn GM, Stratton P, et al. Association of germline mutations in the fumarate hydratase gene and uterine fibroids in women with hereditary leiomyomatosis and renal cell cancer. Arch Dermatol. Dec; 2008 144(12):1584-1592. [PubMed: 19075141]

76. Garg K, Tickoo SK, Soslow RA, Reuter VE. Morphologic features of uterine leiomyomas associated with hereditary leiomyomatosis and renal cell carcinoma syndrome: a case report. Am J Surg Pathol. Aug; 2011 35(8):1235-1237. [PubMed: 21753700]

77. Alam NA, Barclay E, Rowan AJ, et al. Clinical features of multiple cutaneous and uterine leiomyomatosis: an underdiagnosed tumor syndrome. Arch Dermatol. Feb; 2005 141(2):199-206. [PubMed: 15724016]

78. Badeloe S, van Spaendonck-Zwarts KY, van Steensel MA, et al. Wilms tumour as a possible early manifestation of hereditary leiomyomatosis and renal cell cancer? Br J Dermatol. Mar; 2009 160(3):707-709. [PubMed: 19183174]

79. Carvajal-Carmona LG, Alam NA, Pollard PJ, et al. Adult leydig cell tumors of the testis caused by germline fumarate hydratase mutations. J Clin Endocrinol Metab. Aug; 2006 91(8):3071-3075. [PubMed: 16757530]

80. Lamba M, Verma S, Prokopetz R, Pierscianowski TA, Jabi M, Moyana T. Multiple cutaneous and uterine leiomyomas associated with gastric GIST. J Cutan Med Surg. Dec; 2005 9(6):332-335. [PubMed: 16699905]

81. Matyakhina L, Freedman RJ, Bourdeau I, et al. Hereditary leiomyomatosis associated with bilateral, massive, macronodular adrenocortical disease and atypical cushing syndrome: a clinical and molecular genetic investigation. J Clin Endocrinol Metab. Jun; 2005 90(6):3773-3779. [PubMed: 15741255]

82. Eder JP, Shapiro GI, Appleman LJ, et al. A phase I study of foretinib, a multi-targeted inhibitor of c-Met and vascular endothelial growth factor receptor 2. Clin Cancer Res. Jul 1; 2010 16(13): 3507-3516. [PubMed: 20472683]

83. Choueiri TK, Vaishampayan U, Rosenberg JE, et al. Phase II and biomarker study of the dual MET/VEGFR2 inhibitor foretinib in patients with papillary renal cell carcinoma. J Clin Oncol. Jan 10; 2013 31(2):181-186. [PubMed: 23213094]

84. Gordon MS, Hussey M, Nagle RB, et al. Phase II study of erlotinib in patients with locally advanced or metastatic papillary histology renal cell cancer: SWOG S0317. J Clin Oncol. Dec 1; 2009 27(34):5788-5793. [PubMed: 19884559]

85. Khoo SK, Bradley M, Wong FK, Hedblad MA, Nordenskjold M, Teh BT. Birt-Hogg-Dube syndrome: mapping of a novel hereditary neoplasia gene to chromosome 17p12-q11.2. Oncogene. Aug 23; 2001 20(37):5239-5242. [PubMed: 11526515]

86. Schmidt LS, Warren MB, Nickerson ML, et al. Birt-Hogg-Dube syndrome, a genodermatosis associated with spontaneous pneumothorax and kidney neoplasia, maps to chromosome 17p11.2. Am J Hum Genet. Oct; 2001 69(4):876-882. [PubMed: 11533913] 
87. Nickerson ML, Warren MB, Toro JR, et al. Mutations in a novel gene lead to kidney tumors, lung wall defects, and benign tumors of the hair follicle in patients with the Birt-Hogg-Dube syndrome. Cancer Cell. Aug; 2002 2(2):157-164. [PubMed: 12204536]

88. Benhammou JN, Vocke CD, Santani A, et al. Identification of intragenic deletions and duplication in the FLCN gene in Birt-Hogg-Dube syndrome. Genes Chromosomes Cancer. Jun; 2011 50(6): 466-477. [PubMed: 21412933]

89. Luijten MN, Basten SG, Claessens T, et al. Birt-Hogg-Dube syndrome is a novel ciliopathy. Hum Molec Genet. Jul 6.2013

90. Medvetz DA, Khabibullin D, Hariharan V, et al. Folliculin, the product of the Birt-Hogg-Dube tumor suppressor gene, interacts with the adherens junction protein p0071 to regulate cell-cell adhesion. PloS one. 2012; 7(11):e47842. [PubMed: 23139756]

91. Gaur K, Li J, Wang D, et al. The Birt-Hogg-Dube tumor suppressor Folliculin negatively regulates ribosomal RNA synthesis. Hum Molec Genet. Jan 15; 2013 22(2):284-299. [PubMed: 23077212]

92. Pavlovich CP, Grubb RL 3rd, Hurley K, et al. Evaluation and management of renal tumors in the Birt-Hogg-Dube syndrome. J Urol. May; 2005 173(5):1482-1486. [PubMed: 15821464]

93. Khoo SK, Kahnoski K, Sugimura J, et al. Inactivation of BHD in sporadic renal tumors. Cancer Res. Aug 1; 2003 63(15):4583-4587. [PubMed: 12907635]

94. da Silva NF, Gentle D, Hesson LB, Morton DG, Latif F, Maher ER. Analysis of the Birt-HoggDube (BHD) tumour suppressor gene in sporadic renal cell carcinoma and colorectal cancer. $\mathrm{J}$ Med Genet. Nov; 2003 40(11):820-824. [PubMed: 14627671]

95. Menko FH, van Steensel MA, Giraud S, et al. Birt-Hogg-Dube syndrome: diagnosis and management. Lancet Oncol. Dec; 2009 10(12):1199-1206. [PubMed: 19959076]

96. Linehan WM, Pinto PA, Bratslavsky G, et al. Hereditary kidney cancer: unique opportunity for disease-based therapy. Cancer. May 15; 2009 115(10 Suppl):2252-2261. [PubMed: 19402075]

97. Pena-Llopis S, Vega-Rubin-de-Celis S, Liao A, et al. BAP1 loss defines a new class of renal cell carcinoma. Nat Genet. Jul; 2012 44(7):751-759. [PubMed: 22683710]

98. Kapur P, Pena-Llopis S, Christie A, et al. Effects on survival of BAP1 and PBRM1 mutations in sporadic clear-cell renal-cell carcinoma: a retrospective analysis with independent validation. Lancet Oncol. Feb; 2013 14(2):159-167. [PubMed: 23333114]

99. Farley MN, Schmidt LS, Mester JL, et al. Germline BAP1 mutation predisposes to familial clearcell renal cell carcinoma. Molec Cancer Res. EPub May 242013.

100. Popova T, Hebert L, Jacquemin V, et al. Germline BAP1 Mutations Predispose to Renal Cell Carcinomas. Am J Hum Genet. May 14.2013

101. Bodmer D, Eleveld M, Ligtenberg M, et al. Cytogenetic and molecular analysis of early stage renal cell carcinomas in a family with a translocation $(2 ; 3)(\mathrm{q} 35 ; \mathrm{q} 21)$. Cancer Genet Cytogenet. Apr 1; 2002 134(1):6-12. [PubMed: 11996788]

102. Bonne AC, Bodmer D, Schoenmakers EF, van Ravenswaaij CM, Hoogerbrugge N, van Kessel AG. Chromosome 3 translocations and familial renal cell cancer. Curr Mol Med. Dec; 2004 4(8): 849-854. [PubMed: 15579032]

103. Eleveld MJ, Bodmer D, Merkx G, et al. Molecular analysis of a familial case of renal cell cancer and a t(3;6)(q12;q15). Genes Chromosomes Cancer. May; 2001 31(1):23-32. [PubMed: 11284032]

104. Foster RE, Abdulrahman M, Morris MR, et al. Characterization of a 3;6 translocation associated with renal cell carcinoma. Genes Chromosomes Cancer. Apr; 2007 46(4):311-317. [PubMed: 17205537]

105. Kanayama H, Lui WO, Takahashi M, et al. Association of a novel constitutional translocation $\mathrm{t}(1 \mathrm{q} ; 3 \mathrm{q})$ with familial renal cell carcinoma. J Med Genet. Mar; 2001 38(3):165-170. [PubMed: 11238683]

106. Koolen MI, van der Meyden AP, Bodmer D, et al. A familial case of renal cell carcinoma and a $\mathrm{t}(2 ; 3)$ chromosome translocation. Kidney Int. Feb; 1998 53(2):273-275. [PubMed: 9461085]

107. Comprehensive molecular characterization of clear cell renal cell carcinoma. Nature. Jul 4; 2013 499(7456):43-49. [PubMed: 23792563] 
108. Liaw D, Marsh DJ, Li J, et al. Germline mutations of the PTEN gene in Cowden disease, an inherited breast and thyroid cancer syndrome. Nat Genet. 1997; 16(1):64-67. [PubMed: 9140396]

109. Gustafson S, Zbuk KM, Scacheri C, Eng C. Cowden syndrome. Semin Oncol. Oct; 2007 34(5): 428-434. [PubMed: 17920899]

110. Zbuk KM, Eng C. Cancer phenomics: RET and PTEN as illustrative models. Nat Rev Cancer. Jan; 2007 7(1):35-45. [PubMed: 17167516]

111. Lynch ED, Ostermeyer EA, Lee MK, et al. Inherited mutations in PTEN that are associated with breast cancer, cowden disease, and juvenile polyposis. Am J Hum Genet. 1997; 61(6):12541260. [PubMed: 9399897]

112. Tan MH, Mester JL, Ngeow J, Rybicki LA, Orloff MS, Eng C. Lifetime cancer risks in individuals with germline PTEN mutations. Clin Cancer Res. Jan 15; 2012 18(2):400-407. [PubMed: 22252256]

113. Kondo K, Yao M, Kobayashi K, et al. PTEN/MMAC1/TEP1 mutations in human primary renalcell carcinomas and renal carcinoma cell lines. Int J Cancer. Jan 15; 2001 91(2):219-224. [PubMed: 11146448]

114. Letouze E, Martinelli C, Loriot C, et al. SDH Mutations Establish a Hypermethylator Phenotype in Paraganglioma. Cancer cell. Jun 10; 2013 23(6):739-752. [PubMed: 23707781]

115. Astuti D, Latif F, Dallol A, et al. Gene mutations in the succinate dehydrogenase subunit SDHB cause susceptibility to familial pheochromocytoma and to familial paraganglioma. Am J Hum Genet. 2001; 69(1):49-54. [PubMed: 11404820]

116. Amar L, Baudin E, Burnichon N, et al. Succinate dehydrogenase B gene mutations predict survival in patients with malignant pheochromocytomas or paragangliomas. J Clin Endocrinol Metab. Oct; 2007 92(10):3822-3828. [PubMed: 17652212]

117. Ricketts C, Woodward ER, Killick P, et al. Germline SDHB mutations and familial renal cell carcinoma. J Natt Cancer Inst. Sep 3; 2008 100(17):1260-1262.

118. Vanharanta S, Buchta M, McWhinney SR, et al. Early-onset renal cell carcinoma as a novel extraparaganglial component of SDHB-associated heritable paraganglioma. Am J Hum Genet. Jan; 2004 74(1):153-159. [PubMed: 14685938]

119. Morris MR, Maina E, Morgan NV, et al. Molecular genetic analysis of FIH-1, FH, and SDHB candidate tumour suppressor genes in renal cell carcinoma. J Clin Pathol. Jul; 2004 57(7):706711. [PubMed: 15220362]

120. Ricketts CJ, Shuch B, Vocke CD, et al. Succinate dehydrogenase kidney cancer: an aggressive example of the Warburg effect in cancer. J Urol. Dec; 2012 188(6):2063-2071. [PubMed: 23083876]

121. Crino PB, Nathanson KL, Henske EP. The tuberous sclerosis complex. N Engl J Med. Sep 28; 2006 355(13):1345-1356. [PubMed: 17005952]

122. Identification and characterization of the tuberous sclerosis gene on chromosome 16. Cell. Dec 31; 1993 75(7):1305-1315. [PubMed: 8269512]

123. Kozlowski P, Roberts P, Dabora S, et al. Identification of 54 large deletions/duplications in TSC1 and TSC2 using MLPA, and genotype-phenotype correlations. Hum Genet. May; 2007 121(3-4): 389-400. [PubMed: 17287951]

124. van Slegtenhorst M, de Hoogt R, Hermans C, et al. Identification of the tuberous sclerosis gene TSC1 on chromosome 9q34. Science. Aug 8; 1997 277(5327):805-808. [PubMed: 9242607]

125. Dabora SL, Jozwiak S, Franz DN, et al. Mutational analysis in a cohort of 224 tuberous sclerosis patients indicates increased severity of TSC2, compared with TSC1, disease in multiple organs. Am J Hum Genet. Jan; 2001 68(1):64-80. [PubMed: 11112665]

126. Dixon BP, Hulbert JC, Bissler JJ. Tuberous sclerosis complex renal disease. Nephron Exp Nephrol. 2011; 118(1):e15-20. [PubMed: 21071977]

127. Bissler JJ, Kingswood JC, Radzikowska E, et al. Everolimus for angiomyolipoma associated with tuberous sclerosis complex or sporadic lymphangioleiomyomatosis (EXIST-2): a multicentre, randomised, double-blind, placebo-controlled trial. Lancet. Mar 9; 2013 381(9869):817-824. [PubMed: 23312829] 


\section{Clinical Summary}

- Currently there are ten inherited cancer susceptibility syndromes which are associated with an increased risk of renal tumors, of varying pathological types.

- Therapeutic options for the treatment of renal tumors associated with cancer susceptibility syndromes are expanding, and are discussed herein. 


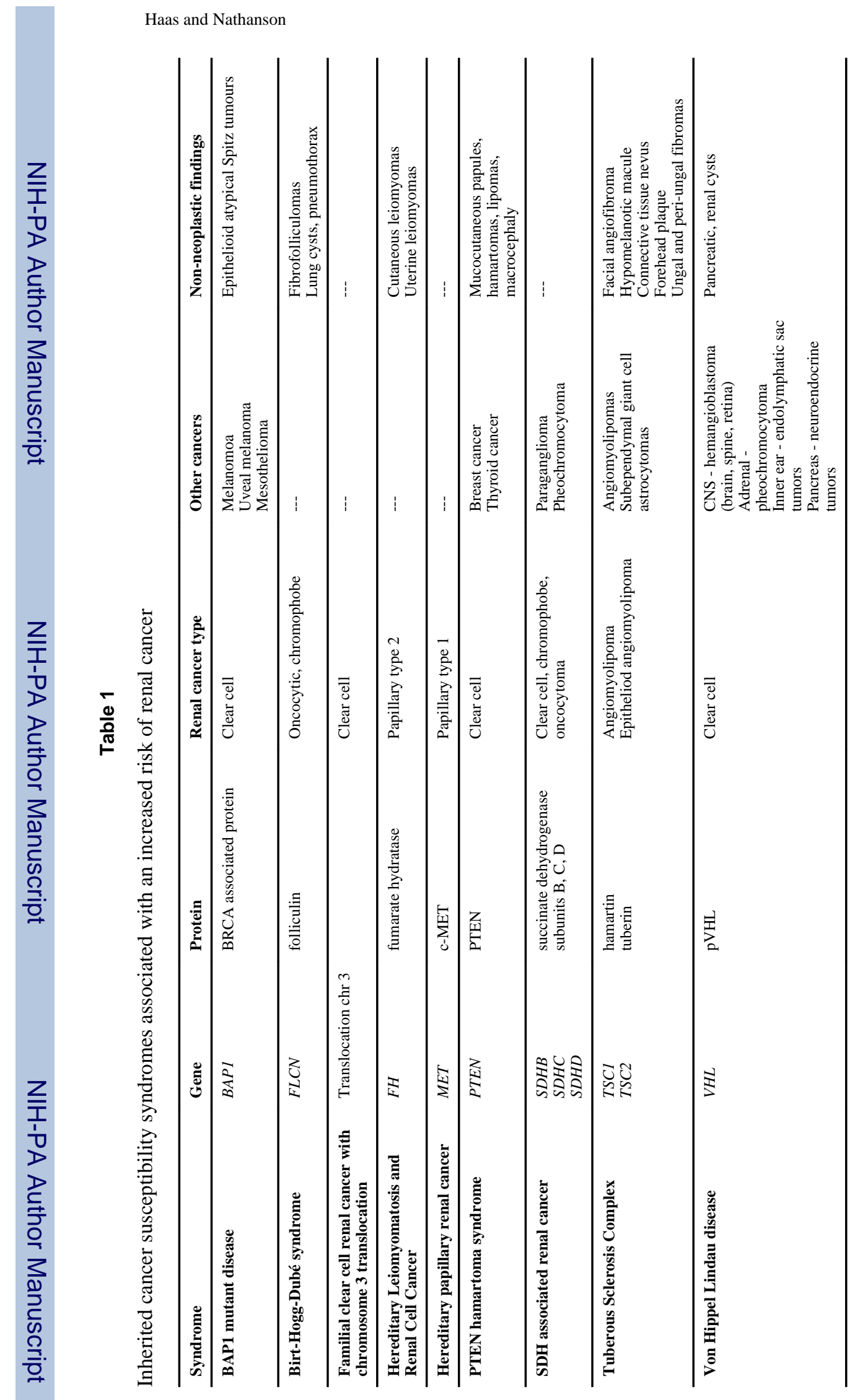

Page 17 